\title{
Perancangan Sistem Informasi Perpustakaan Berbasis Web Pada SMA Efata Soe
}

\author{
Raymond Maulany ${ }^{1}$, Nyongki Bako ${ }^{2}$ \\ 1,2Fakultas Teknologi Informasi, Universitas Advent Indonesia

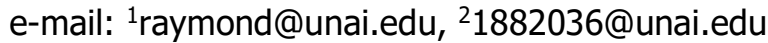

\begin{abstract}
Abstrak
Peran teknologi informasi sudah menjadi kebutuhan manusia pada saat ini. Sistem informasi perpustakaan merupakan suatu hal yang sangat penting dalam dunia pendidikan karena perpustakaan adalah merupakan jendela dunia. SMA Efata Soe ingin memiliki Aplikasi Perpustakaan Berbasis Web. Penggunaan teknologi tersebut akan berfungsi sebagai sebuah sistem terintegrasi, untuk menyediakan informasi serta mendukung pengambilan keputusan manajemen dalam sebuah perpustakaan.

Sistem Aplikasi Perpustakaan berbasis web ini, memanfaatkan perangkat keras dan perangkat lunak komputer, serta prosedur manual model manajemen dan juga pengambilan keputusan basis data. Penggunaan platform memudahkan akses sistem di mana saja dengan menggunakan perangkat yang terkoneksi di dalam jaringan. Namun dalam perancangan ini, sistem yang digunakan baru bersifat dalam jaringan lokal sekolah, belum tersambung ke jaringan internet. Dengan adanya sistem ini sangat membantu perpustakaan SMA Efata Soe dalam pengelolaan koleksi buku.
\end{abstract}

Kata kunci: perpustakaan, sistem informasi, berbasis web

\section{Design of Web Based Library Information System at SMA Efata SOE}

\begin{abstract}
The role of information technology has become a human need at this time. Library information system is a very important thing in the world of education because the library is a window to the world. Efata Soe High School wants to have a Web Based Library Application. The use of this technology will function as an integrated system, to provide information and support management decision making in a library.

This web-based library application system utilizes computer hardware and software, as well as manual management model procedures and database decision making. The use of platforms makes it easy to access the system anywhere by using devices connected to the network. But in this design the new system used is in the local school network, not yet connected to the internet network. With this system, it really helps the Efata Soe High School library in managing book collections.
\end{abstract}

Keywords: library, information systems, web-based

\section{Pendahuluan}

Perpustakaan adalah institusi atau lembaga yang menyediakan koleksi bahan perpustakaan tertulis, tercetak ${ }_{\llcorner}$dan terekam sebagai pusat sumber informasi yang diatur menurut sistem dan aturan yang baku dan didayagunakan untuk keperluan pendidikan, penelitian ${ }_{\llcorner}$dan rekreasi intelektual bagi masyarakat. Perpustakaan secara umum bertujuan untuk melakukan layanan informasi kepada masyarakat. Tujuan khusus dibedakan oleh jenis perpustakaannya. 
Dengan demikian, ukuran perkembangan perpustakaan banyak diukur dari penerapan teknologi informasi yang digunakan dan bukan dari skala ukuran lain seperti besarnya gedung perpustakaan yang

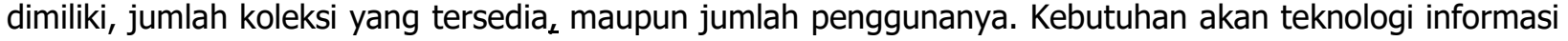
sangat berhubungan dengan peran perpustakaan sebagai kekuatan dalam penyebaran informasi ilmu pengetahuan dan kebudayaan.

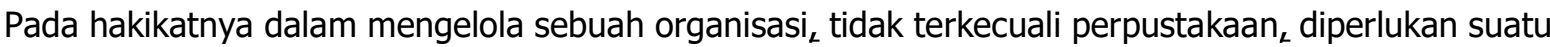
serangkaian kegiatan manajemen. Manajemen adalah suatu kegiatan untuk mencapai tujuan, melalui kerja orang-orang lain yang meliputi perancangan dan sifat-sifat usaha kelompok dalam rangka untuk mencapai tujuan, dengan penggunaan modal berupa materiil maupun non materiil dan juga untuk mengantisipasi hambatan yang akan dihadapi. Dengan kata lain konsep dasar manajemen adalah perencanaan, pengorganisasian, pelaksanaan dan pengendalian suatu aktivitas yang bertujuan untuk mengalokasikan sumber daya sehingga mempunyai nilai tambah [1].

Gambaran di atas menjadi sebuah objek penelitian untuk menerapkan Sistem Informasi Perpustakaan berbasis web pada SMA Efata Soe. Dengan aplikasi ini, akan mempermudah pelayanan dan akses informasi serta pengelolaan data perpustakaan, seperti mempermudah pencarian buku, sistem keanggotaan, peminjaman dan pengembalian buku ${ }_{L}$ serta pelaporan secara berkala. Sehingga akan diperoleh efisiensi pekerjaan staf perpustakaan dalam pengelolaan buku perpustakaan, penyajian informasi yang lebih mudah dan interaktif, memberikan layanan yang lebih baik kepada pengguna layanan perpustakaan.

\section{Metodologi}

Dalam membangun dan mengembangkan aplikasi ini menggunakan metode waterfall. Waterfall merupakan salah satu metode pengembangan sistem informasi yang bersifat sistematis dan sekuensial, artinya setiap tahapan dalam metode ini dilakukan secara berurutan dan berkelanjutan [2] .

Menurut [3], waterfall mode/sebagai salah satu teori dasar dan seakan wajib dipelajari dalam konteks siklus hidup perangkat lunak, merupakan sebuah siklus hidup yang terdiri dari mulai fase hidup perangkat lunak sebelum terjadi hingga pascaproduksi. Waterfall model memiliki definisi bahwa sebuah hidup perangkat lunak memiliki sebuah proses yang linear dan sekuensial.

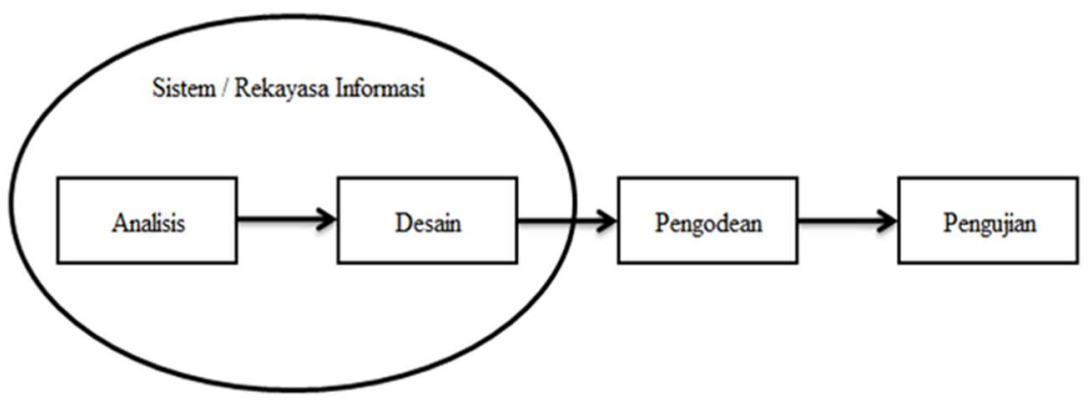

Gambar 11 Waterfall Life Cycle

\section{Analisa Sistem}

Dari analisa tersebut diharapkan dapat menghasilkan sebuah aplikasi yang dapat membantu serta mempermudah petugas perpustakaan untuk proses menyimpan data buku, dan membuat pelaporan perpustakan secara cepat dan akurat. UML adalah sebuah bahasa yang berdasarkan grafik atau gambar untuk memvisualisasikan, menspesifikasikan, membangun ${ }_{L}$ dan melakukan dokumentasi dari sebuah sistem pengembangan perangkat lunak berbasis Objek (Object Oriented programming) 


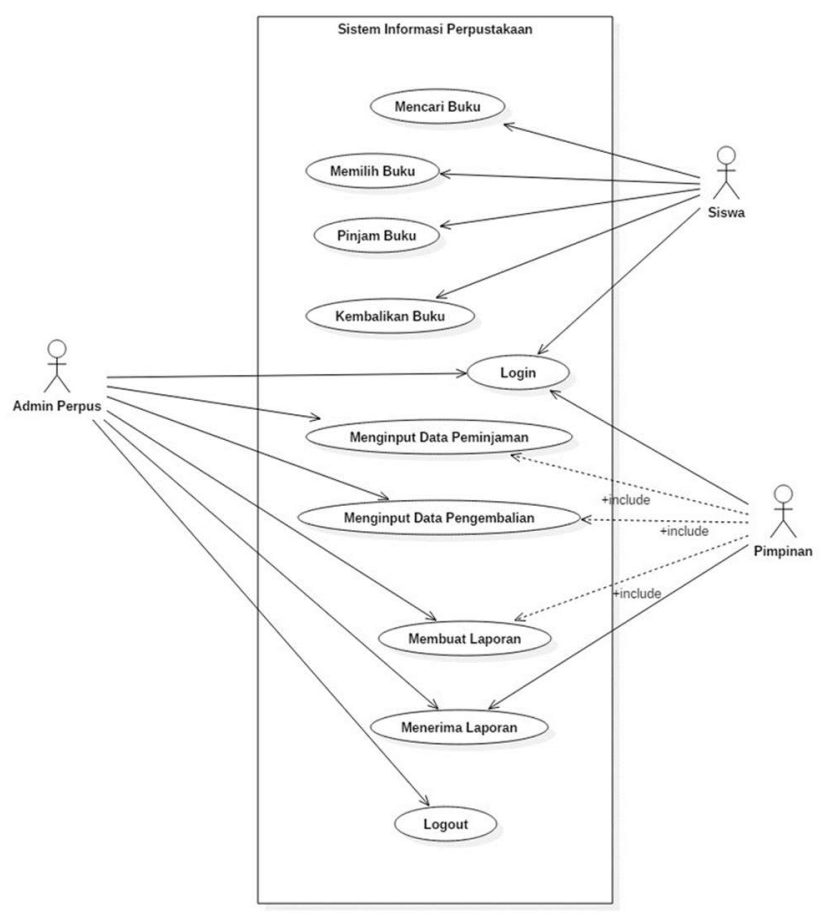

Gambar 12 Use Case Diagram

Use Case Diagram di atas memiliki kegiatan sebagai berikut:

1. Sistem yang mencakup seluruh proses atau kegiatan peminjaman.

2. Yang melakukan kegiatan ada beberapa aktor sebagai berikut yaitu siswa, Admin atau petugas perpustakaan $_{L}$ dan pimpinan.

3. Login dan Logout, Memilih Buku, Pinjam Buku, Kembalikan Buku, Meng-input Data Peminjaman, Meng-input Data Pengembalian, dan Membuat Laporan Menerima Laporan.

Sesuai dengan penjelasan simbol di atas dapat dijelaskan sistem yang berjalan adalah sebagai berikut:

1. Apabila ada siswa yang ingin meminjam buku, maka harus datang langsung ke perpustakaan ada petugas yang melayani.

2. Di perpustakaan tersebut, siswa bebas memilih buku yang sudah tersedia sesuai keinginan.

3. Petugas perpustakaan berhak melakukan input data peminjam.

4. Petugas menyerahkan buku kepada siswa.

5. Pembuatan laporan peminjaman beserta pengembalian dilakukan oleh petugas, dan menyerahkannya kepada pimpinan. 


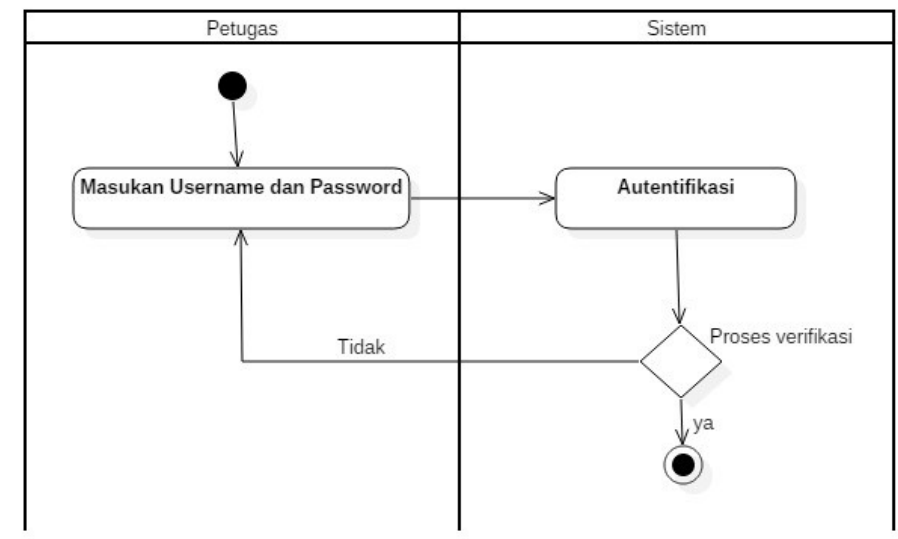

Gambar 13 Activity Diagram Login

Activity Diagram Login Yang Berjalan secara terperinci dapat disebutkan :

1. 1 Initial Node, Objek yang diawali.

2. Action state dari sistem di antaranya, masukan username dan password, serta autentifikasi apakah berhasil login atau tidak.

3. 1 Final State, Objek yang diakhiri.

Dapat dijelaskan bahwa, petugas sebelum masuk ke sistem tersebut, harus melakukan login yaitu

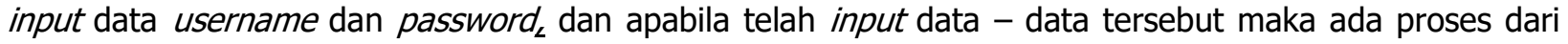
sistem apakah data yang dimasukan sudah benar atau tidak, apabila tidak benar maka dari sistem akan memberitahukan.

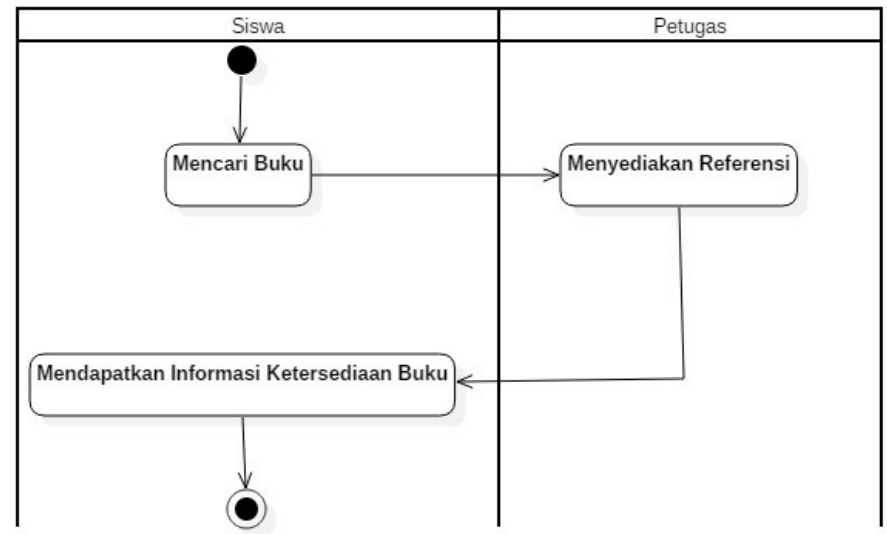

Gambar 14 Activity Diagram Memilih Buku

Lebih lanjut dapat dijelaskan bahwa:

1. 1 Initial Node, Objek yang diawali.

2. 3 Action state dari sistem di antaranya mencari buku, menyediakan referensi, mendapatkan informasi ketersediaan buku.

3. 1 Final State, Objek yang diakhiri

Sesuai dengan kategori di atas dapat dijelaskan bahwa: siswa yang ingin mencari buku, datang ke perpustakaan akan ada petugas perpustakaan yang mana membantu menyediakan referensi, sehingga mempermudah siswa tersebut. 


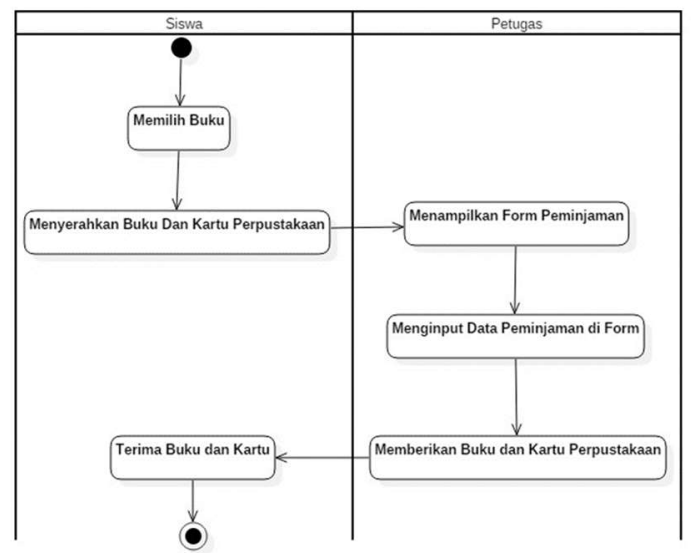

Gambar 15 Activity Diagram Peminjaman

Activity Diagram Peminjaman Buku yang berjalan adalah:

1. 1 Initial Node, Objek yang diawali.

2. 6 Action state dari sistem di antaranya, memilih buku, menyerahkan buku, dan kartu perpustakaan, menampilkan form Peminjaman, input data peminjaman di form, memberikan buku dan kartu perpustakaan, terima buku dan kartu.

3. 1 Final State, Objek yang diakhiri

Dari penjelasan simbol di atas dapat di jelaskan bahwa prosedur sistem yang berjalan sebagai berikut: Siswa yang ingin meminjam buku datang ke perpustakaan, ada petugas di perpustakaan. Siswa memilih buku yang dipinjam kemudian menyerahkan kartu perpustakaan dan buku tersebut kepada petugas, maka petugas akan meng-input data peminjaman, setelah itu petugas menyerahkan kartu dan buku.

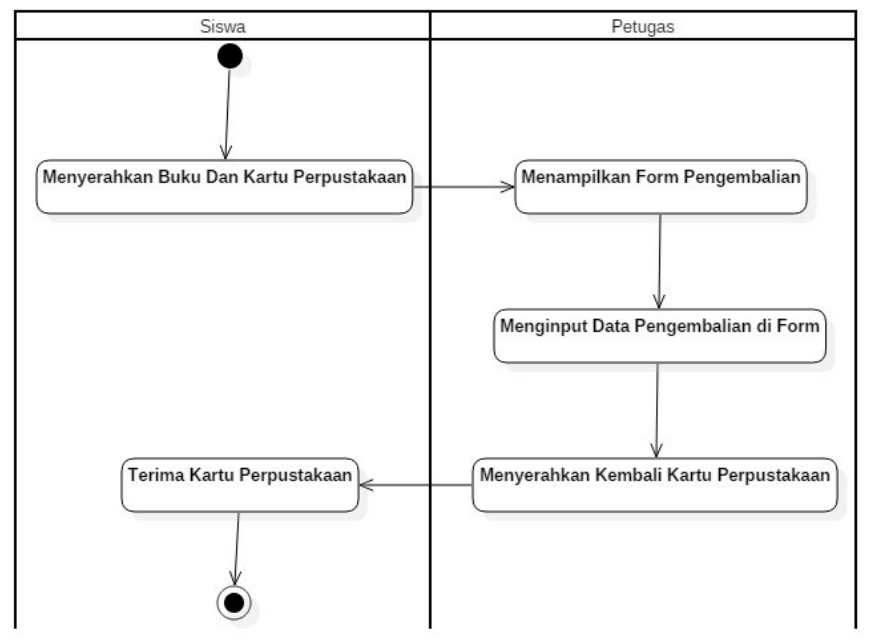

Gambar 16 Activity Diagram Pengembalian

Activity Diagram Peminjaman buku yang berjalan lebih lanjut dapat dijelaskan bahwa:

1. 1 Initial Node, Objek yang diawali. 
2. 5 Action state dari sistem di antaranya, menyerahkan buku dan kartu perpustakaan, menampilkan form pengembalian, input data pengembalian di form, menyerahkan kartu perpustakaan, terima kartu perpustakaan.

3. 1 Final State, Objek yang diakhiri

Sesuai dengan keterangan di atas dapat dijelaskan bahwa, siswa yang telah meminjam buku dan ingin mengembalikannya sesuai dengan waktu yang sudah ditetapkan, maka siswa harus datang ke perpustakaan dan di perpustakaan akan ada petugas perpustakaan, kemudian siswa menyerahkan buku yang sudah di pinjam beserta kartu perpustakaan dan dari pihak petugas akan melakukan input data, setelah itu petugas menyerahkan kembali kartu perpustakaan kepada siswa tersebut.

Berdasarkan Activity Diagram tersebut dapat digambarkan proses sistem baru yang akan dijalankan, sehingga dapat dipahami bagaimana nantinya sistem ini berjalan dan fungsi-fungsi yang dibutuhkan dalam proses sistem berjalan.

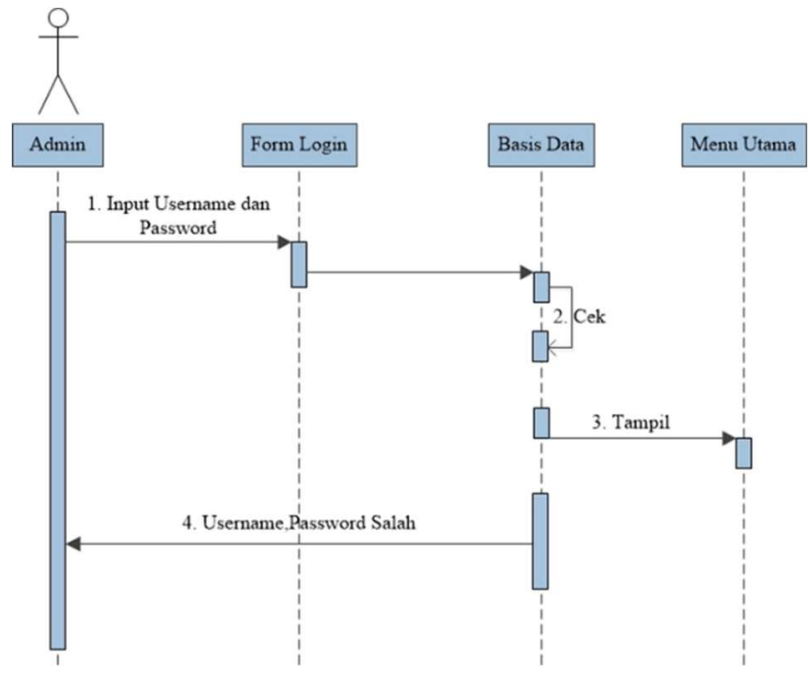

Gambar 17 Sequence Diagram Login

Sequence Diagram yang berjalan:

1. 1 aktor yang melakukan kegiatan antara lain admin perpustakaan atau petugas.

2. 4 Message spesifikasi dari komunikasi antar objek yang di mana memuat data - data informasi tentang aktifitas yang terjadi secara langsung.

3. 3 Lifeline di antaranya Form login, basis data dan Menu utama sistem. 


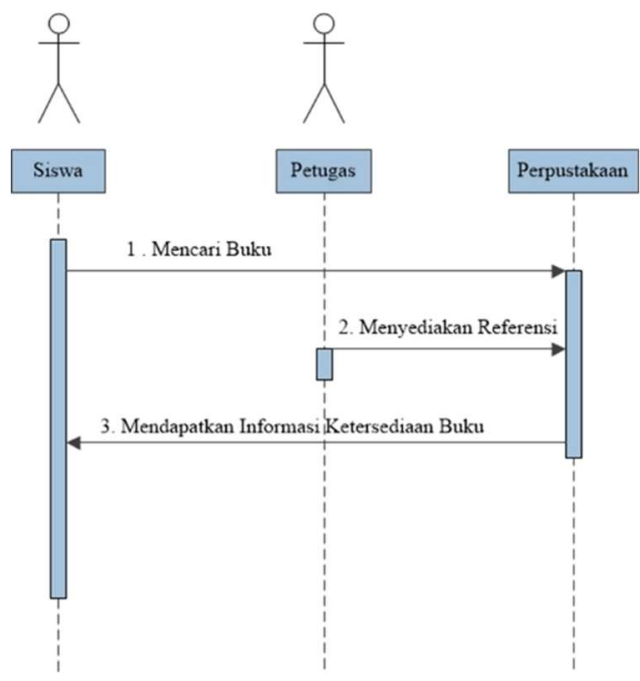

Gambar 18 Sequence Diagram Memilih Buku

Sequence Diagram yang berjalan:

1. 2 aktor yang melakukan kegiatan antara lain: siswa dan petugas.

2. 3 Message spesifikasi dari komunikasi antar objek yang di mana memuat data - data informasi tentang aktivitas yang terjadi secara langsung.

3. 1 Lifeline di antaranya adalah perpustakaan.

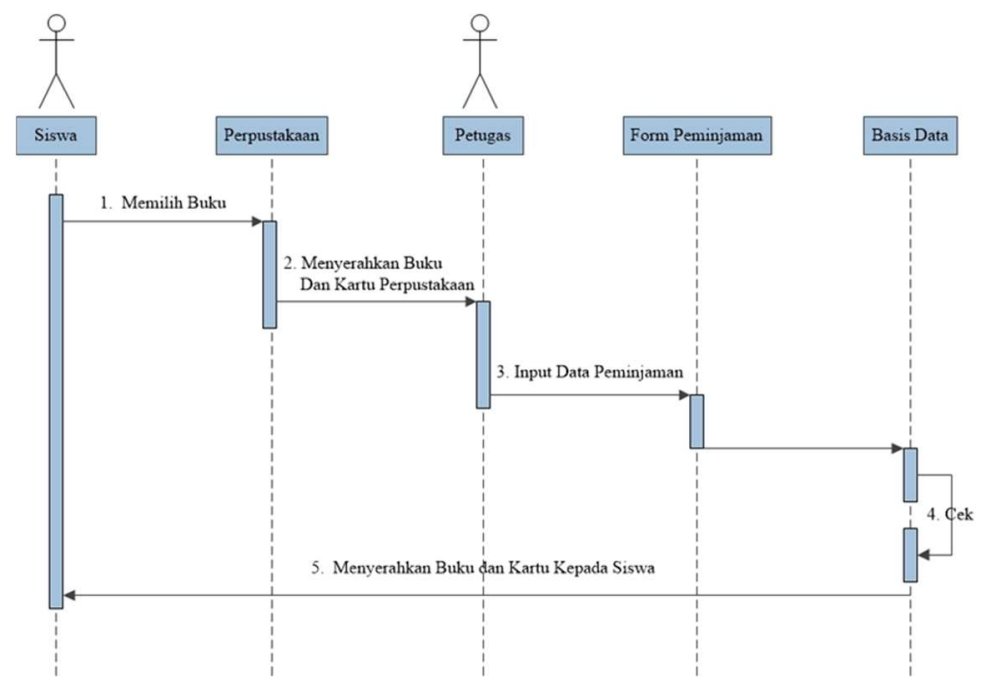

Gambar 19 Sequence Diagram Peminjaman

Sequence Diagram yang berjalan :

1. 2 aktor yang melakukan kegiatan antara lain: Siswa dan petugas.

2. 5 Message spesifikasi dari komunikasi antar objek yang di mana memuat data - data informasi tentang aktivitas yang terjadi secara langsung

3. 3 Lifeline di antaranya adalah perpustakaan, perpustakaan dan form peminjaman beserta basis data. 


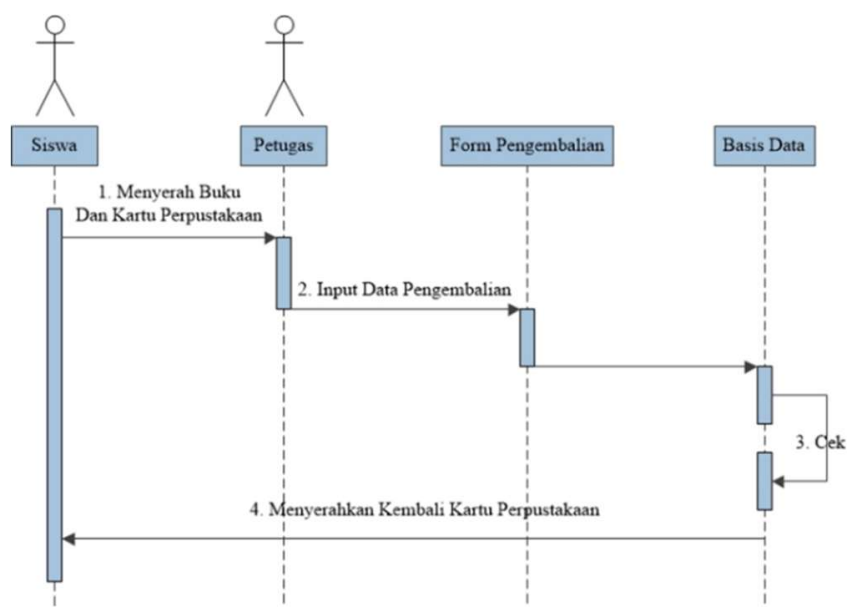

Gambar 20 Sequence Diagram Pengembalian

Lebih lanjut Sequence Diagram yang berjalan adalah:

1. 2 Aktor yang melakukan kegiatan antara lain: Siswa dan petugas.

2. 4 Message spesifikasi dari komunikasi antar objek yang di mana memuat data - data informasi tentang aktifitas yang terjadi secara langsung

3. 2 Lifeline di antaranya adalah form pengembalian dan basis data.

Dari hasil perancangan sistem berdasarkan diagram yang dihasilkan maka tercipta tabel dan kamus data, yang terdiri yaitu :

1. Tabel Admin Perpustakaan

2. Tabel Anggota

3. Tabel Buku

4. Tabel Kategori

5. Tabel Peminjaman

6. Tabel Peminjaman detail

7. Tabel Pengembalian

8. Tabel Pengembalian detail

\section{Hasil}

Dalam proses pengembangan sistem informasi tersebut dengan tujuan yang akurat untuk membantu proses operasional pada perpustakaan agar berjalan lancar. Tampilan antar muka hasil dari perancangan sebagai berikut

Library SMA Efata Soe

E-Mall Adoress

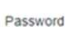


Gambar 11 tampilan halaman login dalam keadaan kosong. Di mana halaman login tersebut bertujuan untuk petugas atau admin input username dan password sebelum menggunakan sistem tersebut untuk operasional perpustakaan. Jika petugas input username dan password benar, maka akan dibawa kehalaman antarmuka dari sistem tersebut dan apabila salah maka akan muncul notifikasi username dan password yang anda masukan salah.

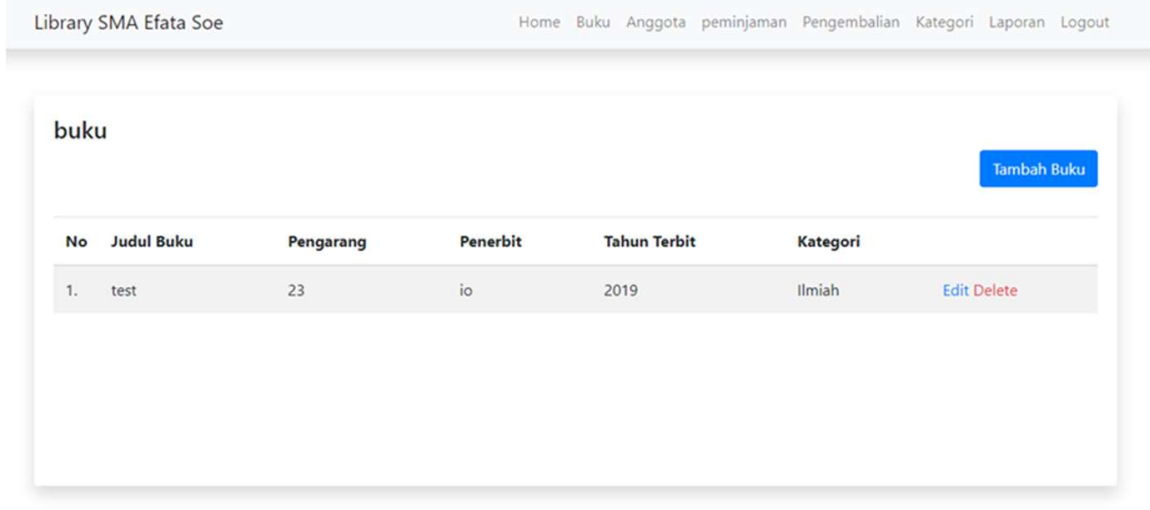

Gambar 22 Halaman Input Buku

Tampilan input buku ini khusus digunakan untuk menambah buku baru dan hanya bisa diakses oleh admin yang memiliki hak akses.

Pada halaman ini memeliki beberapa keterangan sebagai berikut yang pertama adalah sebagai berikut:

1. Tombol tambah buku digunakan untuk menambah buku baru.

2. Edit digunakan untuk mengedit data buku yang sudah tersimpan

3. Delete digunakan untuk menghapus data buku yang sudah di-input

4. Halaman isi buku baru digunakan untuk memasukan data buku

5. Tombol simpan digunakan untuk menyimpan data buku yang sudah di-input.

6. Kembali atau cance/digunakan jika tidak melanjutkan ke proses input.

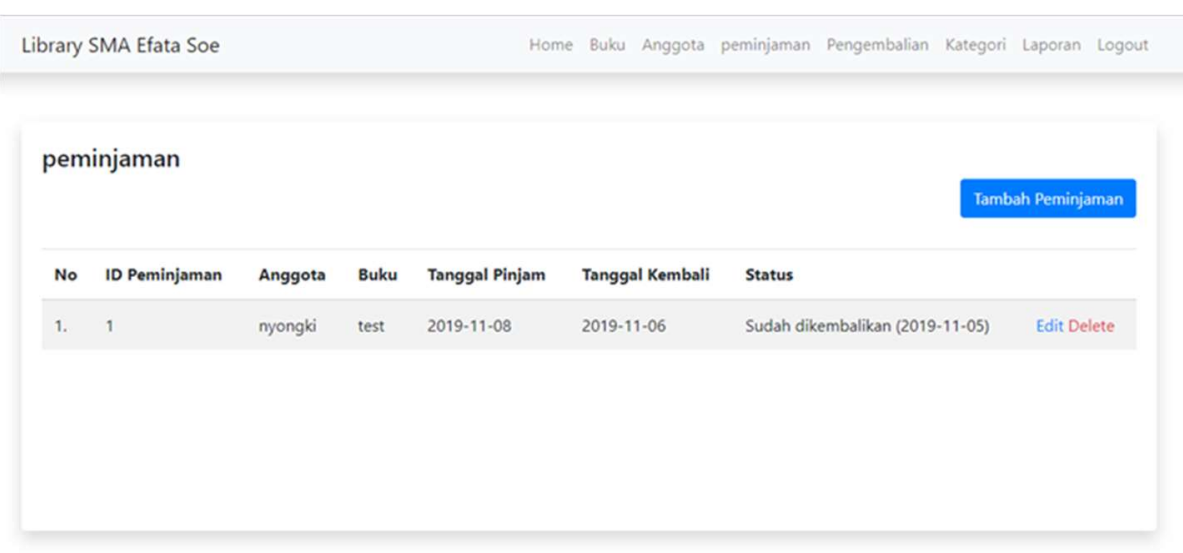

Gambar 23 Halaman Peminjaman

Tampilan input peminjaman ini digunakan untuk memasukkan data peminjaman buku baru dan juga meng-update peminjaman buku yang akan diperpanjang. Tampilan ini bisa diakses oleh administrator yang memiliki hak akses.

1. Tombol tambah peminjaman adalah digunakan untuk masuk pada isi data peminjaman

2. Tombol save atau simpan digunakan untuk menyimpan data peminjam yang sudah diisi. 
3. Tombol cance/ digunakan untuk membatalkan proses tersebut.

4. Tombol delete digunakan untuk menghapus
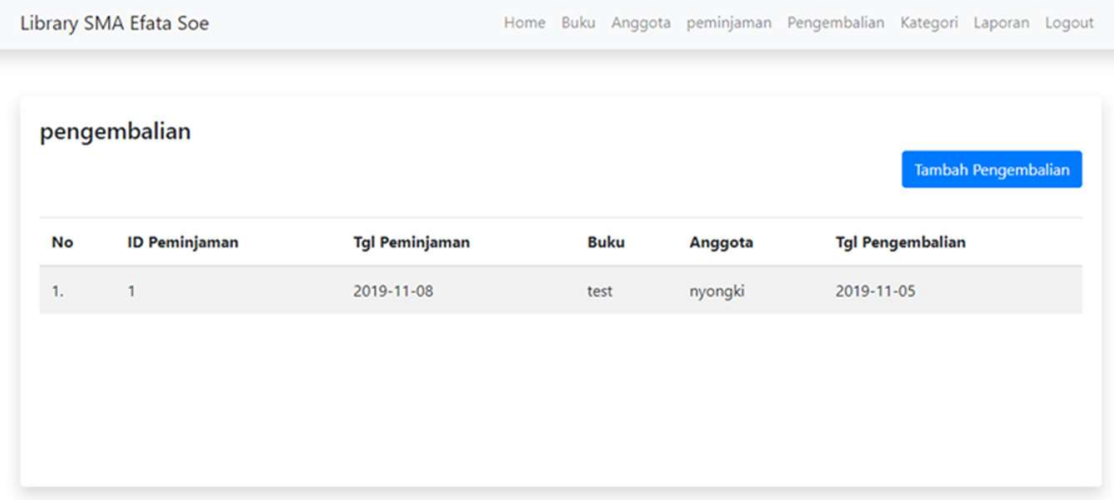

Gambar 24 Halaman Pengembalian

Tombol tambah pengembalian digunakan untuk memilih idpeminjaman dan juga tanggal kembali.

1. Tombol save digunakan untuk menyimpan

2. Tombol cance/digunakan untuk membatalkan proses tersebut.

\section{Kesimpulan}

Hasil dari penelitian dapat disimpulkan bahwa dengan ada sistem informasi perpustakaan si SMA Efata So'e berbasis web ini sudah membantu proses pengolahan manajemen perpustakaan. Mengurangi terjadi kesalahan khususnya dalam sirkulasi buku. Sistem sudah bisa menginventaris buku serta melakukan pencatatan pengolahan data perpustakaan dengan baik. Untuk masa yang akan datang diharapkan sistem informasi ini bisa dikembangkan lagi seperti bisa tersambung sistem secara online.

\section{Referensi}

[1] A. Prastowo, Manajemen Perpustakaan Sekolah Profesional., Yogyakarta: Diva Press, 2012.

[2] R. E. Nasution, Implementation Sms Gateway In The Development Web Based Information System Schedule Seminar Thesis., 2012: UNILA, 2012, p. 118.

[3] S. Rizky, Konsep Dasar Rekayasa Perangkat Lunak, Jakarta: PT Prestasi Pustakaraya, 2011.

[4] . J. Widyarina, Perancangan Sistem Informasi Promosi Makanan Berbasis Web, Bekasi: Swasta, 2014.

[5] A. Satrio , Perancangan Sistem Informasi Penjualan Sparepart Motor Berbasis Web pada UD Jaya Motor Variasi, Tangerang: Skripsi, 2013.

[6] Prasetyo, Perancangan Sistem Informasi Penjualan Barang Kemasan Produk PAA CV. Ismie Jaya, Tangerang: Skripsi, 2013.

[7] A. Wicaksono, Manajemen Perpustakaan Sekolah Dasar Negeri Di Kecamatan Mandari Mandiraja Kabupaten Banjanegara, Yogyakarta.: Skripsi, 2014. 